\title{
NEMZETKÖZI \\ VÁNDORMOZGALOM ÉS \\ KEZELÉSE DÉL-KOREÁBAN
}

\section{Koudela Pál}

\section{ÖSSZEFOGLALÓ}

Dél-Korea nemzetfelfogása rányomja bélyegét a migrációval kapcsolatos politikájára a diaszpórával, a munkaerő-bevándorlással és az integrációval kapcsolatban egyaránt. Az elmúlt évtizedek demográfiai változásaira, a csökkenő termékenységre, az elöregedő korszerkezetre és a zsugorodó népességre, s a mindezekből fakadó gazdasági problémákra a kormány aktívan reagál. A közelmúltban ez a nemzetgazdasági tervezésben és a multikulturális programokban is megmutatkozott, habár a változások a központositott adminisztráció által és gyorsan zajlanak, mégis egy nyitottabb társadalom irányába mutatnak. Továbbra is meghatározó a migrációs politika gazdasági érdekeknek való alárendelése, ám az emberi-jogi szempontok itt is egyre jobban érvényesülnek. A Koreai Köztársaság jelentős változáson megy keresztül, a bevándorlás és az országban élő külföldiek számának növekedése számottevő, így az ország a tágabb kelet-ázsiai térségben geopolitikai és migrációs értelemben is köztes helyet vívott ki magának.

Tárgyszavak: nemzetközi vándorlás, Dél-Korea, migrációs politika, diaszpóra politika

Koudela Pál

Kodolányi János Főiskola

E-mail: pkoudela@yahoo.com 


\section{BEVEZETÉS}

A Koreai Köztársaság migrációval kapcsolatos jogi és intézményi helyzete alapvetően a társadalom etnikai homogenitásán alapul, a bevándorlás mértéke és a bevándorlók száma is igen alacsony az országban (Seol - Skrentny 2004). Dél-Korea a magas etnikai homogenitás elvárás és a globalizációs folyamatok feszültségei miatt egy sajátos hierarchikus rendszert épített ki. Kelet-Ázsia migrációs politikája ma sokszor szembe kerül a gazdasági racionalizmussal, ott tehát leginkább a Meyers (2000: 1251) által „nemzeti identitás” megközelítésnek nevezett szemlélet meghatározó, mely szerint a migrációs politikákat elsősorban a történeti tapasztalat befolyásolja. Brubaker (1990: 380-381.) szerint alapvetően az I. világháború előtt alakultak ki azok a kulturális idiómák, amik a politikai döntéshozatalban az államérdek fogalmát, az állampolgárság restriktív elemeit uralják, felülírva a demográfiai, a gazdasági és a katonai érdekeket is. A nemzeti diskurzus tehát még a nemzetépítés korszakára nyúlna vissza, s ez szorosan összefügg az állami érdekeket meghatározó történelmi és térbeli tényezőkkel minden egyes ország esetében. Míg a japán nemzetállam eszménye a Meidzsirestauráció nemzetközi viszonyrendszerében gyökerezik, addig a koreai inkább térbeli, s azt a Kína, Japán és az Egyesült Államok háromszögön belüli önértelmezés alakítja, mintegy köztes államként jelölve ki helyzetét (Rozman 2006: 152).

Japánnal ellentétben azonban Dél-Koreában egyre több jele mutatkozik annak, hogy a gazdasági és a demográfiai problémák kezelésében a kormány a bevándorlást is serkenteni igyekszik, így annak különösen tágabb regionális hálózatai folyamatosan erősödnek. Japánban a Meidzsi-restauráció egyik államépítő elve a modern etnikai nacionalizmus ideológiai megteremtése volt olyan eszközökkel, mint pl. a sintó államvallássá tétele. Dél-Korea is adoptálta a modern nemzetközpontú eszméket, pl. a szociál-darwinizmust (Shin 2006), ám sokkal inkább egyfajta átfogó világmagyarázatként értelmezve azt szemben Japánnal, ahol a „legrátermettebb túlélésének elve” egyértelműen megfelelt a korszak politikai törekvéseinek (Tikhonov 2010: 9-12.). Koreával kapcsolatban a nacionalizmushoz példaként a leggyakrabban a máig népszerü Tangun-mítoszt említik' (Seo 2007: 55, 허동현 2009). A nacionalizmus ékes bizonyitékai a bevándorlókról alkotott kép a mítosz tükrében (오정미 2015), vagy a kormány határon túli koreai közösségekhez való viszonya. Ám felmerül a kérdés, hogy vajon mekkora szerepe van mindebben a geopolitikának és mekkora az etnikai nacionalizmus-

\footnotetext{
${ }^{1}$ Tangun mitikus király, az első koreai állam alapítója, kitől a nép minden tagja származik, s ekként a közös őstől származás
} közös vérségi köteléket, közösséget is teremt. 
nak. Habár ez utóbbi továbbra is meghatározó a bevándorlás kezelésében is, ám a Koreai Köztársaság nemrégiben már multikulturális programot hirdetett meg, s ennek vannak látható jelei a migrációt és annak kezelését illetően is, így korántsem lehet egysíkúan megítélni az ország helyzetét ebben a tekintetben sem.

Dél-Korea egyéb szempontból is különleges helyzetben van, hiszen technikailag háborúban áll másik felével, s ezt a megfogalmazást annak az interpretációnak a jegyében tettük, amely alapvetően azt feltételezi, hogy a kettészakadt ország két felének sorsa - ugyan egy bizonytalan jövőbeni ponton -, de mégiscsak konvergál (Pollack-Chung 1999, Levin 1999, Hwang 2010, Delissen Ceuster - Gelézeau 2013). Jelen körülmények között tehát Dél-Korea határon túli etnikai csoportjait nem lehet egyszerü diaszpórákként leírni, és a feléjük irányuló politikájának jellemzőit csupán hozzájuk való viszonyulásában keresni. Tekintettel kell lenni a két ország viszonyára, különleges összetevőire is (Armstrong 2007: 92). A két fél a konfliktusok ellenére osztozik olyan közös tulajdonságokban is, amelyeket a nemzetre vonatkoztathatunk, s a Napfényes politika nem is olyan régen mindkét oldalon ismét előtérbe hozta azon közös szándékot, ami az újraegyesítést jelenti (Son 2006). A Koreai Köztársaság regionális helyzete tehát összetett, s ez rányomja bélyegét a migrációs politikájára is. Sajátságos Dél-Korea regionális helyzete azért is, mert a térségben meghatározó szuperhatalmak árnyékában történetileg és geopolitikailag is háttérbe szorult. Az évezredes kínai hegemónia, a 20. század első felében Japán megszállása, a másodikban pedig az USA dominanciája, védelme és hidegháborús érdekszférája határozta meg helyzetét; azt követően azonban máris a térség diplomáciai egyensúlyát fenntartó központba került, s tette ezt mindössze röpke másfél évtized alatt (Rozman 2006: 152). Az elkövetkezőkben Dél-Korea nemzetközi vándorlását és annak kezelését a sajátosan átmeneti helyzetének a tükrében fogjuk elemezni.

A Koreai Köztársaság több szempontból is igen jelentős helyet foglal el Kelet-Ázsia migrációs rendszerében: egyfelől az elmúlt évtizedek gyors gazdasági növekedése révén igen jelentős munkaerő-piaci szereplővé vált, különösen a globális hálózatokban nőtt meg a szerepe. Szöul a Saskia Sassen által elsőként leírt globális városok között már az ezredfordulóra kiemelt helyet szerzett (Hill - Kim 2000), ennek hatása érződik a migrációs folyamatok és az azt kezelő politika ellentmondásain is. Ugyanakkor geopolitikai helyzete mellett a migrációs politikában is sajátos átmenetiséggel jellemezhető: hagyományosan Ázsia országai egy a térképre rajzolt képzeletbeli háromszög csücskein igen eltérő migrációs politikai stratégiával jellemezhetőek: Kelet-Ázsia elzárkózó centrumtérség, Délkelet-Ázsia viszont a munkaerő-kivitelre koncentráló, ám határgondokkal küzdő régió, s mindkettő migrációs kapcsolata a főként munkaerő-behoza- 
tallal jellemezhető Közel-Kelettel hagyományosan intenzív (Martin 2013). DélKorea az elmúlt években zárt migrációs politikáját a multikulturalizmus irányába kezdte megváltoztatni, s az integráció területén is hatalmas lépéseket tett, így mára egyszerre vált egy dél felől északra áramló migrációs folyosó központi országává és egyben példamutatóvá annak kezelésében.

Mindemellett továbbra is igen erős a nemzet homogenitásába vetett hit mind a társadalmi közfelfogás, mind a kormányzati politika oldalán, s a bevándorlás növekedéséből fakadó ilyetén feszültségeket eredendően éppen a nagyszámú diaszpóra „hazacsábításával” igyekezett az ország vezetése megoldani. A határon túl élők nemzettestbe történő valamiféle integrálása természetesen nem koreai vagy kelet-ázsiai sajátosság: diaszpóra törvényeket láthatunk Latin-Amerikában és Európában is, hazánk a legközelebbi példa erre. Az elmúlt évtizedben azonban Dél-Korea változtatott ezen a stratégián, és a nem koreai származásúak integrációjára is egyre nagyobb hangsúlyt fektet.

\section{A DÉL-KOREAI DIASZPÓRA ÉS AZ ÁLLAM VISZONYA}

A dél-koreai diaszpóra több mint 7 millió főt számlál, ami mára közel 800 ezerrel nagyobb népesség, mint volt 2003-ban. Tudni kell azonban, hogy a diaszpórát kezelő politika és az ide vonatkozó adatgyűjtés és elemzés is igen tágan értelmezi annak fogalmát, beleértve minden korábbi hullámban kivándorolt koreai leszármazottat, vagy akár csupán kulturális örökséget hordozó, identitásában kötődő személyt. A globális gazdasági hálózatok előnyeit kihasználni igyekvő gazdaságpolitika mindent meg is tesz ennek erősítésére (Choi 2003). Az alábbi táblázat adatai is ennek a definíciónak az eredményeit tükrözik, ezért térnek el ilyen nagymértékben az ENSZ migrációs mátrix statisztika adataitól, mely kb. 2,3 millió Dél-Koreában született, de nem ott élő személyről tud 2013-ra vonatkozóan (United Nations 2013). Habár a Koreai Köztársaság egészen az 1970-es évekig klasszikus kivándorló ország volt - köszönhetően nagyrészt akkori fejletlenségének -, az 1980-as évektől megindult gazdasági, technológiai és társadalmi átalakulás együtt járt azzal a demográfiai átalakulással, ami itt is, mint mindenütt, növekvő munkarerő igénnyel és csökkenő munkaerő-kínálattal járt együtt. Ennek ellenére a magasan képzettek kivándorlása még évtizedekig megfigyelhető és a mai napig tartó jelenség. A migrációs folyamatokban inkább a hazavándorló, koreai származású munkaerő jelentett nagyobb változást. Az ezredfordulót követően azonban csökkenésnek indult a kivándorlás Koreából. 
1. táblázat: A dél-koreaiak száma a világ országaiban és térségeiben, 2015-ben (ezer fö) Number of South Koreans in countries and regions around the world, in 2015 (thousand)

\begin{tabular}{|c|c|c|c|c|c|c|c|c|c|}
\hline Japán & Kína & $\begin{array}{c}\text { Délkelet- } \\
\text { Ázsia }\end{array}$ & USA & $\begin{array}{c}\text { Dél- } \\
\text { Amerika }\end{array}$ & $\begin{array}{r}\text { Európa } \\
\text { vol }\end{array}$ & $\begin{array}{l}\text { Oroszors } \\
\text { tagállam }\end{array}$ & $\begin{array}{l}\text { ág és } \\
\text { k }\end{array}$ & Egyéb & Összes \\
\hline \multirow{2}{*}{856} & \multirow{2}{*}{2586} & \multirow{2}{*}{511} & \multirow{2}{*}{2239} & \multirow{2}{*}{105} & \multicolumn{3}{|c|}{ Összesen: 627} & \multirow{2}{*}{252} & \multirow{2}{*}{7185} \\
\hline & & & & & $\begin{array}{c}\text { Oroszo. } \\
167\end{array}$ & $\begin{array}{l}\text { Üzbeg. } \\
186\end{array}$ & $\begin{array}{c}\text { Kazah. } \\
108\end{array}$ & & \\
\hline
\end{tabular}

Forrás: 외교부 2015: 22

1860-tól indul meg az első jelentős kivándorlási hullám Mandzsúriába és Szibériába (Diener 2006: 204, Huttenbach 1993, Kho 1987: 16), amelynek oka elsősorban a szárazság okozta éhínség és gazdasági válság volt (Seth 2011: 267, Seth 2010: 46), de részben az ipar és vasút fejlődése révén egy „keresleti oldal” is kialakult ott (McKeown 2004: 159). Habár a határellenőrzés, sőt maga a határ is igen homályos volt akkoriban, ezért az északon gazdálkodó farmerek könnyen átszökhettek rajta, egészen 1910-ig mindössze 220 ezer koreai telepedett le Mandzsúriában, még annál is kevesebben, csupán 54 ezren Szibériában, 1920-ra viszont már félmillió, illetve százezer a számuk a két említett területen (Kim, Richard S. 2011: 169). A kivándorlás azonban akkor gyorsult fel igazán, amikor Japán 1910-ben annektálta Koreát, és az elnyomást odáig fokozta, hogy végül még a koreai nyelv használatát is betiltotta.

A II. világháború után természetesen tömeges visszavándorlás indult meg, mintegy másfél millióan költöztek haza Japánból, közülük 1,4 millió Dél-Koreába, de még a Mandzsúriát elhagyó nyolcszázezer koreainak is a fele a kettészakadt ország déli felét választotta, holott ők mind északról származtak. Időközben a Szibériában élő koreai közösséget, vagyis kb. 170 ezer főt Kazahsztánba és Üzbegisztánba deportálták 1937-ben, ahol a rákövetkező év folyamán 40 ezren éhen haltak. Sztálin kétmillió főt érintő áttelepítési programjának keretében a koreai volt az első etnikum, akiket Sztálin teljes egészében kitelepített. A Japánnal vívandó háborútól tartó Szovjetunióban a koreaiak - a japán megszállás alatt lévő területekhez füződő kapcsolataik miatt - gyanúsak voltak. A koreai kisebbség, sok másikkal együtt igazi ellenségképpé vált a harmincas évek Szovjetuniójában (Martin 2001: 335-343., Gelb 1995: 394); mindennek valamint a további kitelepítéseknek köszönhető az, hogy ma félmilliós koreai közösség él Közép-Ázsia országaiban (Pohl 1999: 9-10.).

A következő kivándorlási hullám ezután csak jóval a háborúk után, 1962-től indult meg, ekkor született ugyanis az első modern Kivándorlási törvény, amit kifejezetten a túlnépesedés, a munkaerő-piaci túlkínálat enyhítése és a külföldi deviza iránti növekvő igény miatt alkottak meg. 1945 és 1962 között jellemzően 
diákok mentek Amerikába tanulni, mintegy hatezren, s ugyancsak hatezer katonafeleség, velük pedig további ötezer gyermek telepedett le az Egyesült Államokban (Yu 1983: 24, Yuh 2002). Dél-Korea a hatvanas években a Japánhoz hasonló programmal próbálkozott, és Brazíliában, valamint Argentínában szándékozott koreai agrárközösségeket létrehozni. Ennek érdekében földeket bérelt a két dél-amerikai kormánytól, s ki is küldött számos családot. A szervezés azonban nem sikerült igazán, a terv csődbe ment. A már kiutazott koreaiak mégsem tértek haza: előbb a nagyvárosokban, majd később főként az Egyesült Államokban és Kanadában telepedtek le.

De 1962-től a Koreai Köztársaság nem csupán Dél-Amerikába küldött szerződéses munkásokat, 1963-ban a Közel-Keletre és Nyugat-Németországba bányászokat, 1965-ben pedig ápolónőket. Ám a kivándorlási folyamat felgyorsulását az új, 1965-ös amerikai bevándorlási törvény váltotta ki, ami eltörölte a korábbi kvótákat és korlátozásokat, ezzel lehetővé téve a tömeges bevándorlást az ázsiaiak számára (Kim, II-Soo 1981, Yoon 1997: 67). Az Amerikába vándorlók főként magasan iskolázott, középosztálybeli családok voltak, ugyanakkor az 1988-as szöuli olimpiát követően, a gazdasági prosperitás idején éppen ők költöztek vissza Koreába, így számuk az USA-ban mára csökkenni kezdett. Ezt követően csupán az 1997-es pénzügyi krízis váltott ki újabb kivándorlást, akkor már főként Kanadába, Ausztráliába és Új-Zélandra, és már nem családegyesítés, hanem üzleti vagy egyéb alkalmazás keresése céljából (Yoon 2012: 415).

1962-től dél-koreaiak a legnagyobb számban a Közel-Keletre mentek dolgozni. A munkaerő-kivándorlás 1982-ben tetőzött, abban az évben 200 ezer fő utazott külföldre dolgozni; majd a 1980-as évek közepétől csökkenni kezdett a kivándorlás, majd 1987-től a dél-koreai kormány már nem adott ki engedélyt újabb külföldi munkaerő-közvetítő cégeknek. A munkaerő-közvetítő szolgálat 1991-től csökkentette, majd 1994-ben beszüntette működését, így 1997-ben már csak 17 ezren vándoroltak külföldre munkát vállalni (Lee 2005: 153).

1963 és 1987 között összesen 1,6 millióan hagyták el az országot munkakeresés céljából: 60\%-uk a Közel-Keletre, 30\%-uk pedig külföldi hajókra ment dolgozni. Európába 1973-ig gyakorlatilag csak Nyugat-Németországba vándoroltak dél-koreaiak, s a nagyrészük soha nem is tért vissza hazájába: vagy ott telepedtek le, vagy más európai országba vándoroltak tovább, de a mai napig Németországban él az egyik legnagyobb koreai diaszpóra Európában, 39 ezer fő (외교부 2015: 22). A Közel-Keleten dolgozók átlagosan négy évet, vagyis két terminust töltöttek ott, majd nagyrészük hazatért Koreába, egy kisebb hányaduk pedig Ausztráliába és Kanadába vándorolt. A tartós kivándorlásban is az USA 1965-ös, illetve a 1960-as években és a 1970-es évek elején 
Kanadában és Ausztráliában beiktatott liberális bevándorlási törvények hoztak fordulatot, 1976-ban érve el a csúcsot, 46 ezer dél-koreai emigránssal. (Meg kell jegyezni, hogy a határozott idejü szerződésekkel külföldön dolgozókat leszámítva minden három hónapot meghaladó időtartamot kint töltőt tartós kivándorlónak tekint a dél-koreai migrációs statisztika az adott évre, ezt korrigálják az elemzések egy hosszabb időtartam esetén a befogadó országokban tartós letelepedési státuszt elnyert személyek száma alapján.) Attól kezdve folyamatos hanyatlás következett be, 2002-ben csupán 11 ezer fő volt a kivándorlók száma. 1962 és 1987 között a magas visszavándorlás következtében összességében mindössze 800 ezer dél-koreai telepedett le tartósan külföldön, főként családegyesítés és munkavállalás céljából. Ennek az állománynak a nagy része az Egyesült Államokat választotta: mintegy 600 ezer fő (Lee 2005: 154.) Az Öböl-országokban munkát vállalók iskolázatlan fizikai dolgozók voltak, hazautalásaik, munkaerőpiaci rugalmasságuk és munkahelyi tapasztalataik révén mindenképpen gazdasági hasznot jelentettek Koreának. Az 1970-es évektől ugyanis szabályozta a kormány a munkások külföldi vállalatoknál való alkalmazását. A nem hazai cégeknél 1977-ben még 13,7\% volt a dél-koreai alkalmazottak aránya, 1978-ban már csak 6,8, 1979-ben pedig mindössze 2,9\% - a kivándorló munkaerő durván 98\%-a 1980-ban tehát már dél-koreai vállalatoknál állt alkalmazásban. Így mind az idegenben tevékenykedő vállalatok, mind a munkások nyertek, az előbbiek a magasabb profit, az utóbbiak a nagyobb fizetés formájában (Lee 2005: 157). Ezzel ellentétben a külföldön tartósan letelepülőkre - magasan iskolázott szellemi foglalkozásúak lévén -, általában káros folyamatként, a humán tőke elvesztéseként tekint a koreai szakirodalom (Park 2012, Yoon 1997: 5).

A kivándorlás az 1990-es évekre elvesztette korábbi politikai és gazdasági jelentőségét - 1989-ben eltöröltek minden kiutazási korlátozást, majd 2000-től már a tizenévesek is utazhattak külföldre tanulni -, ám a diaszpóra számában és gazdasági erejében is tovább növekszik, ennek megfelelően az államhoz füződő viszonya fokozottan előtérbe került, mégpedig különböző formákban. Ma az Egyesült Államokban él az egyik legnagyobb dél-koreai közösség, s ebben jelentős szerepe van annak a 806 ezer kivándorlónak, akik 1948 és 2000 között telepedtek le ott (Yu et al. 2002: 72). Ugyanakkor, szintén a 1990-es évektől a Koreai Köztársaság népessége látványosan öregedni, a termékenység pedig csökkenni kezdett. Az elöregedés gyorsabb, mint Japánban, a termékenység pedig a legalacsonyabb az OECD-országok között. 2015-ben a születéskor várható élettartam a két nemre együttesen 80 év, a teljes termékenységi együttható 1,25 volt (ClA World Factbook 2016). 
2. táblázat: A dél-koreai diaszpóra számának alakulása 1991-2015 között (ezer fó) Changes in numbers of South Korean diaspora 1991-2015 (thousand)

$\begin{array}{ccccccccc}1991 & 1995 & 1999 & 2001 & 2003 & 2009 & 2011 & 2013 & 2015 \\ 4832 & 5229 & 5644 & 5654 & 6077 & 6823 & 7176 & 7013 & 7185\end{array}$

Forrás: 외교부 2015: 14, Lee 2005: 150, Choi 2003: 18.

2015-re a diaszpóra Dél-Korea népességének már a 14,6\%-át tette ki, amely 1991 óta közel másfélszeresére nőtt. A 60\%-uk a befogadó ország állampolgára, a maradék pedig, kettő a háromhoz arányban, tartós, illetve ideiglenes letelepülő. Az 1990-es évek elejétől a dél-koreai kormány igen jelentős gazdasági kapcsolatokat épített ki közöttük. Az 1960-as és 1970-es évek agyelszívással kapcsolatos aggodalmát mára az országba visszaáramló tudományos és műszaki humántőke-forrás kiaknázásának igénye váltotta fel (Song 2014). Persze a kormány törekvése nem csak támogatást kap, sok az ellenérv is, hiszen a külföldön élők nem fizetnek adót, nem töltenek sorkatonai szolgálatot, így azonos polgárként bánni velük, konfliktusforrás is. Miközben a diaszpórához füződő viszonyt áthatja az etnikai nacionalizmus, a kettős állampolgárság elfogadása ugyanezen okok miatt ütközött ellenállásba, ráadásul az egyes országokban egészen eltérő a dél-koreai közösségek integrációjának mértéke, amiért Kína pl. aggodalommal figyeli a Koreai Köztársaság ezirányú politikáját.

Dél-Korea számára a középosztály kivándorlását egyfelől nem helyettesíti az alacsonyan képzett munkaerő bevándorlása, mert a humán tőke gyengülését és a munkaerőpiaci kínálat összetételének az innováció számára nem kedvező átalakulását eredményezi. Ezt igazolja az is, hogy a bevándorlók 48\% a H-2 és E-9 vízumokkal rendelkezik, amelyeket a szakképzetlen munkásoknak állítanak ki (Status of Registered Foreigners), erről később bővebben is esik még szó. Dél-Korea esetében ezt az ellentmondást nem lehet a „deskilling” jelenségének tulajdonítani, a bevándorlók többsége alacsonyan képzett, és a szakképzettségük megszerzésére külön erőfeszítéseket tesz a kormány. Másfelől a nemzet egységét egy olyan nacionalista önkép, az etnikai homogenitásba vetett hit alapozza meg, amely a kivándorlókban az egyéni gyengeséget, az etnikailag idegen bevándorlókban pedig a társadalmi rend kockázatát látja. Ez azonban nem csupán egyfajta politikai ideológia, közvélemény vagy posztfeudális maradvány modern köntösben, hanem egyben az egyetlen kapocs a két Korea között (Koudela 2015). 
Dél-Korea történelme viharos sebességgel zajlik. Az 1960-as években még túlnépesedéssel küzdő, szegénységben élő ország belekezdett egy olyan ipari programba, ami mára a világ egyik legfejlettebb technológiáját fejlesztette ki. Az akkor 27 milliós országban az egy före jutó GDP mindössze 100 dollár volt, 2015-ben a 49 milliós országban 36500 dollárt tesz ki ez az érték. Az urbanizáció 30\%-ról 82,5\%-ra emelkedett ezen idő alatt, s ennek egyik jelentős következménye az is, hogy a nemi arány felborult a férfiak javára a falusi térségekben. A gyarmati sorból a hidegháborúba csöppent ország totalitárius berendezkedése egy, az 1980-as években megindult harmadik hullámos demokratizálódás következtében az internet forradalom korában találta magát, miközben másik fele megragadt az 1950-es évek nacionalista, marxista-leninista, hidegháborús, militarista korszakában, szegénységben és technikailag még mindig háborúban Déllel.

Csupán két évtizednek kellett eltelnie ahhoz, hogy az 1970-es években még a túlnépesedés miatt aggódó ország a 1990-es évekre már a népesség radikális csökkenését lássa előre, s kelljen megoldást találnia rá, majd alig egy további évtizedre rá a korábban rendületlenül növekvő gazdaság is stagnálni kezdett. Az első jelentős változást a Korea Köztársaság diplomáciai és gazdasági kapcsolatainak rendezése jelentette a hidegháború után a volt szocialista országokkal, s különösen 1991-et követően a volt Szovjetunióval és 1992 után Kínával (Lee - Bradshaw 1997, Kim, Min-hyung 2016). Dél-Korea ebben az időben az említett országokban élő koreai közösségekkel igyekezett megerősíteni a kapcsolatát: a koreai nyelvtanulást támogatta és a hazautazást könnyítette meg elsők között (Fumagalli 2012: 79, Fumagalli 2006: 186).

Fokozatosan intézményesült a diaszpórához füződő kapcsolat. 1993-ban, Kim Jongszam elnöksége alatt indult az Új politika a határon túli koreaiakért, ami két évvel később a Globalizációs projektbizottság megalapulásához vezetett (Park 2014: 194). 1997-ben megalakult a Határon túli Koreaiak Alapítványa, amelynek három alapcélja már messze túlnyúlt a kormány korábbi elképzeléseinél. Elsődlegesen a koreai diaszpóra nemzeti identitásának erősítése fogalmazódott meg mint célkitűzés, különösen a fiatal generációban, amelynek legfontosabb eszköze az oktatás támogatása, annak kiterjesztése volt, s csak ezt követte a politikai és gazdasági együttműködés létrehozása és folyamatos bővítése mint feladat. Mindezt egy, a befogadó országokban élők, de köztük és az anyaország között is, sőt egy globálisan is kiépítendő kapcsolatháló létrehozásának igénye egészítette ki (Overseas Koreans Foundation). 
Hamarosan a körülmények is közrejátszottak, hogy a kapcsolat tovább erősödjön anyaország és diaszpóra között. A gazdasági válság hatására Dél-Korea arra kérte őket, különösen a gazdag nyugati országokban élő közösségeinek tagjait, hogy minél többet fektessenek be a koreai gazdaságba, s hogy a kapcsolat ne legyen egyoldalú, 1999-ben hatályba lépett a 6015 sz., a Bevándorlásról és a határon túli koreaiak jogi helyzetéről szóló törvény (Act on the Immigration). Ennek következményeképpen a külföldi koreaiak gyakorlatilag dél-koreai állampolgárságnak megfelelő státuszt kaptak: szabadon utazhattak ki és be a határon, indithattak vállalkozást, kezdhettek bármiféle tevékenységbe és vásárolhattak ingatlant Koreában. A diaszpóra fele azonban kirekedt a juttatott jogokból, mert a törvény a korábbi koreai állampolgárság igazolását tette szükségessé, s azok, akik 1948 előtt vándoroltak ki: főként a Szovjetunióba és Kínába, ilyennel nem rendelkeztek. Következésképp hamar vita kerekedett (Lee 2002), aminek eredményeként az Alkotmánybíróság döntést hozott, s annak megfelelően a törvényt át kellett alakitani.

A 2004-ben életbe lépett módosításból kivették a korábbi állampolgárságra vonatkozó részt, s így már megfelelt az egyenlőség elvének (Park - Chang 2005: 2). A Kínában élő koreaiak hirtelen két állampolgárság birtokosai lettek, ami viszont élesen szembeütközött Kína állampolgársági törvényével, de hasonló gondok merültek fel Oroszország esetében is. Időközben - ugyancsak kínai mintára - az alapítvány éves gyüléseket kezdett rendezni. 2002-ben a diaszpóra nemzetközi üzleti együttmüködésének fejlesztése érdekében létrejött a Világ Koreai Üzleti Egyezménye, amelynek éves találkozói közül a tizenötödiket 2016 szeptemberében rendezték háromezer hazai és nemzetközi koreai üzletember részvételével (Lee, Yu-sup 2016).

Az 1948. december 20-án életbe lépett Állampolgársági törvény hasonlóképpen a térség többi országáéhoz, vérségi elvre épült: az ugyanis koreai apától való születés után járt, megszerzéséhez mindenképpen le kellett mondani más ország állampolgárságáról. A honositás sem volt egyszerủ, még házasság esetén sem jutott a házastárs automatikusan állampolgársághoz, hanem azt külön kellett kérvényeznie, s egyenként bírálták el (Boll 2007: 441, Law No. 16 of 1948: 20). 2010-ben azonban a kormány újabb lépést tett, hogy elismerje a kettős állampolgárságot, ám csupán korlátozott mértékben. Magasan képzett külföldiek, házasság és adoptálás útján koreai családba került személyek és a koreai diaszpóra 65 év feletti tagjai kerültek ily módon a hatásköre alá - mindezzel a diaszpóra és a nemzet közötti kapcsolatot erősítendő (Lee 2010). Végül 2011-ben a külföldön letelepedett koreaiak a szavazati jogot is megkapták, ezzel 
mintegy betetőzve a homogén etnikai nemzet transznacionális komplexumának megalkotását.

A kettős állampolgárság fejlődése azonban nem lenne érthető csupán a nemzet ilyen közösségi szempontja felöl. 1997-ben az Igazságügyi Minisztérium állásfoglalását követően, valamint mind a hazai civilszervezetek, mind az ENSZ nyomására az Állampolgársági törvényt olyan módon egészitették ki, hogy azontúl már koreai állampolgárságú anya után is kaphasson állampolgárságot a születendő gyermek, ne csupán az 1948-as eredeti törvényi rendelkezésnek megfelelően az apától (Moon 2000: 163-164).

Az új évezred elején az akkor már gyarapodó kettős állampolgárok olyan kiváltságokhoz jutottak, amik irritálták a hazai lakosságot. Ilyen volt pl. a két év kötelező katonai szolgálat alól való mentesség is. A keletkező feszültségek hatására 2003-ban módosították a Kötelező katonai szolgálatról szóló törvényt, ami immár kizárta a tartósan külföldön tartózkodókat a katonáskodás elkerülésének lehetőségéből (Kim, Sungmoon 2007). Mindez nagymértékben megfelelt a közhangulatnak, ám 2005-ben a Nemzetgyülés elutasította a javaslatot, ezzel hatalmas felháborodást keltve országszerte. Miközben a diaszpóra kapcsolathálókat épít ki, az információ növekvő sebességgel áramlik, s az ellátóláncok gyorsabban tudják a változó igényeket kielégíteni, ezzel azonban új keresletet is indukálnak a befogadó országban (Choi 2003: 20). A transznacionális migráns szervezetek jelentős mértékben hozzájárultak Dél-Korea globális exportnövekedéséhez, s a kormány a fiatal nemzedéknek kereskedelmi tanfolyamot is tart, mely egyben a hazai kötődés és identitás erősitését szolgálja (World-Okta 2014).

Már az 1960-as évektől cél volt, ám csak ma, igazán fejlett gazdaságként képes Dél-Korea a magasan iskolázottakat, kifejezetten a tudósokat és mérnököket haza vonzani. Ennek érdekében 1999-ben egy online közösséget is létrehozott a Koreai tudósok és mérnökök globális hálózatát, amelynek célja kifejezetten a nemzetközi koreai tudományos közösség tudásának hazai hasznosítása. Jelenleg tizenhárom országban egymillió tagja van a hálózatnak, s hetven különböző szolgáltatást nyújt, melyet a Tudományos és Technológiai Minisztérium támogat a Jövő Létrehozása terv keretében (About KOISEN). Song Cshang Csu (2014: 8, 2015) szerint mára már maga a diaszpóra gyakorol politikai nyomást a kormányra, hogy fejlessze a hálózatokat, amelyek összekötik őket az anyaországgal, s ennek hátterében erős nemzeti identitásuk áll. 


\section{BEVÁNDORLÁS, POLITIKA ÉS HAZATÉRŐK KOREÁBA}

Az állam diaszpórához fűződő viszonya egyértelműen a gazdag, tőkeerős és/ vagy magasan képzettek bevándorlásának segitéséhez köthető, ám az elöregedő társadalom, és a munkaerő-piaci egyensúly felborulása a szakképzetlen migránsok iránti keresletet is megteremtette már az 1980-as években. Bármennyire is szelekcionista a koreai migrációs politika a diaszpórához kapcsolódóan, a bevándorló munkások, elsőként a kínai koreaiak mégiscsak megtalálták a módját, hogy munkához jussanak Koreában. A kormány Japánhoz hasonlóan a munkaintenzív termelés munkaerő problémáját persze elsősorban annak délkelet-ázsiai országokba való áttelepítésével kívánta megoldani, ugyanakkor már 1986-ban - a Kína és Dél-Korea közötti diplomáciai viszony 1992-es helyreállítása előtt - meghirdette a Kereső kampányt a szétszakitott családok részére (김현미 2009). A munkaerő-piaci feszültséget az elöregedés és a munkaintenzív iparágak fejlődése mellett az is növelte, hogy a társadalom egyre szélesebb rétegei kezdték elutasítani a kétkezi munkákat a növekvő jólét, az iskolázottsági szint és a bérszínvonal közepette, s az 1980-as évek végére kialakult egy duális munkaerőpiac, amelyhez mondhatni kényszerủen alkalmazkodott a kormány intézményi programja (Renzaho 2016: 428).

A vállalatok növekvő nyomására, de a szakszervezetek véleményével szemben elsőként 1991-ben indult az Ipari és technikai gyakornoki program, ami lehetővé tette, hogy olyan vállalatok, amelyeknek van külföldi érdekeltsége, Koreába is behozzanak külföldi munkaerőt; természetesen korlátozott számban és annak ürügyén, hogy a munkások majd szakmai tovább- vagy átképzést kapnak ott. A külföldiek száma nem haladhatta meg az 50 főt vagy a munkaerő 10\%-át az egyes vállalatoknál, s habár féléves képzési programokról volt szó, azt a foglalkoztatók egy évre meghosszabbithatták, sőt a feltételek gyakorlatilag lehetővé tették a programban résztvevők teljes állású alkalmazását is. Az ellentmondásos helyzet nem sokáig maradt fenn: két évre rá, 1993-ban egy átfogóbb Ipari gyakornoki programot alapítottak, ami már egy évre szóló szerződéseket kínált a külföldi munkaerőnek, s további egy év hosszabbítást engedélyezett (Lee, Kyu Young 2016: 7, Lu 2016: 92). Az első kvóta 1993-ban 20 ezer fő volt, ami aztán rohamosan nőtt: 1994-ben 50 ezer, 1996-ban pedig már 80 ezer fö legális munkavállalását tette lehetővé; a valóságban viszont 1994-ben 24 ezer, 1996-ban 68 ezer, az ezredfordulóra azonban 100 ezerhez közeli értéket ért el a gyakornoki vízummal beutazók száma. Ekkoriban tipikusan magán toborzó vállalatok közvetítették a külföldi munkaerőt a koreai vállalatokhoz. 
Az 1990-es évek növekvő munkaerő-bevándorlása azonban gyakori viszszaélésekhez, a munkaerő illegális foglalkoztatásához és más, a hazai és nemzetközi szervek által is kifogásolt problémákhoz vezetett, melynek következtében a kormány az ILO-val közösen kidolgozott egy átfogó Foglalkoztatás engedélyezési rendszert, ami 2004-ben kezdte meg müködését. 1993 után ugyanis számos próbálkozás született, pl. 1997-ben egy újabb rendszer jött létre, amely az alkalmazás és a képzés kapcsolatát oly módon igyekezett megoldani, hogy egyfajta, a gyakornok vagy segéd és a rendes alkalmazott közötti státuszban alkalmazta a külföldi munkásokat két éves szerződésekkel, amiket egy évre lehetett hosszabbítani, s a képzés elvileg munkaidőben zajlott. Ám ez sem vált be; a külföldi munkavállalókat nem védte a Munkajogi törvény és képzést valójában nem is kaptak, de a foglalkoztatók sem akarták a már gyakorlatot szerzett dolgozóikat elengedni három év után, s mindezen az sem segített, hogy 2001-ben a két év gyakornok, egy év munkavállaló felépítésben az arányokat megcserélték (Hahn - Choi 2006: 8). 1995-ben ugyan kiterjesztették a baleseti és egészségbiztosítást, valamint a Munkajogi törvény egyes kitételeit - mint a kényszermunka, az erőszak alkalmazása vagy a túldolgoztatás tiltása - a gyakornok vendégmunkásokra is, sőt a minimálbért is kötelezően megkapták ettől kezdve, mindez azonban nem volt elégséges (Seol 2000: 10).

Miközben a szakszervezetek és egyéb civil szervezetek azon vitáztak, hogy az ipari gyakornokok jogai milyen mértékben vannak biztosítva, s a kormány egyre több intézkedést hozott az ügy érdekében, idővel tehát a vendégmunkás segédek helyzete kedvezőbbé vált, mint a hazai gyakornokoké, ami ugyancsak paradox helyzetet teremtett, s átfogó megoldásra várt (최홍엽 1996). Az 1990-es évek végére a vendégmunkások fizetése is kezdte a piaci szintet elérni, és a vízumuk lejártával egyre többen választották annak illegális túllépését a hazautazás helyett, 1998-ban pedig az összes bevándorlóra kiterjesztették a Munkajogi törvény hatályát. Akiknek lejárt a vízuma, azok pedig sokszor nem mentek haza, hanem más vállalatoknál helyezkedtek el, de érkeztek az országba turista vízummal is sokan, hogy aztán munkát vállaljanak Szöulban és környékén. Mindennek a mértékéről különböző becslések láttak napvilágot: volt olyan számítás, amely az 1990-es évek derekától 2002-re 32-ről 65\%-ra látta emelkedni az illegálisan elhelyezkedett gyakornokok számát (서울경인지역평등노조 2014), mások mérsékeltebb véleménynek adtak hangot, s úgy látták, hogy 1994-ról 2000-re 4-ről 20\%-ra emelkedett az illegálisan foglalkoztatottak aránya (Seok 2009: 123). Az illegális munkások 
között szintén a kínaiak voltak túlsúlyban, mintegy a fele közülük került ki, s ők is többnyire (27\%) koreai-kínaiak voltak (Yoo 2003: 211).

2003-ban tehát megszületett a Külföldi dolgozók alkalmazásáról szóló törvény (Act on Foreign Workers), amely számtalan munkajogi alapelvet magában foglalt. Deklarálta a külföldi munkaerővel szembeni diszkrimináció tiltását, a hazai foglalkoztatás preferenciáját, s a foglalkoztató felelősségét ez ügyben, biztosítékokat a bérkifizetéssel kapcsolatos mulasztások és visszaélésekkel szemben, valamint három évben határozta meg a foglalkoztatás maximumát, s ezen belül háromszori munkahelyváltást tett lehetővé (Yoo 2005: 8). A foglalkoztatás rendszere különbséget tesz külföldi munkavállaló és koreai nemzetiségú külföldi munkavállaló között, az előbbiek számára kiváltható vízumtípus az E-9, míg az utóbbiaknak a H-2-es vízum áll rendelkezésre. Az előbbi csupán a kézmúiparban, az építkezéseken valamint a halászat, mezőgazdaság és állattartásban nyújt munkalehetőséget. A három év lejárta után az alkalmazottnak el kell hagynia az országot, és legalább hat hónapig nem is jelentkezhet újra a programba. A szigorítások következtében jelenleg munkahelyet is csupán indokolt esetben - pl. munkahelyi erőszak vagy jogtalanságok esetén - áll módjában váltani a külföldi alkalmazottnak. Ezen korlátozásokkal az a pozitívum állítható szembe, hogy Dél-Korea reintegrációs programot is hirdetett a hazatérők számára (Employment Permit System), ami támogatást nyújt otthoni vállalkozások indításához, munkalehetőségek kereséséhez (Employment and Labor).

A Foglalkoztatott engedélyezési rendszer azonban még mindig nehézségekkel küzd. A nyelvvizsga-követelmény ellenére akadnak kommunikációs problémák, a bevándorlók nehezen tudják a jogaikat érvényesíteni, megvédeni; a foglalkoztatók pedig továbbra is visszaélnek ezzel a helyzettel. A rendszer ilyen formában leginkább azt a célt szolgálja, hogy a bevándorlók ne telepedhessenek le tartósan az országban (Kim, Soojin 2014: 27). Az eltartottsági arányt és azt is figyelembe véve, hogy Dél-Korea milyen nagymértékben fejleszti szabadkereskedelmi kapcsolatait egyezmények révén, akár az is elképzelhető, hogy a jelenlegi bevándorlásszabályozási folyamat egy tartós letelepedési engedélyhez vezessen. A közvélemény egyelöre kedvezően viszonyul a bevándorláshoz, legalábbis az állampolgárság tekintetében. 1998 és 2010-között 16-ról 56\%-ra nőtt azok aránya, akik támogatják a bevándorlók állampolgárságának megszerzését (Mundy 2013). 
3. táblázat: A Dél-Koreába érkező bevándorlók száma, állampolgárság és státusz szerint a föbb küldő országokból, 2015-ben

Number of immigrants arriving into South Korea by citizenship and status from major sending countries, in 2015

\begin{tabular}{rccccccc} 
& Kína & Thaiföld & $\begin{array}{c}\text { Üzbe- } \\
\text { gisztán }\end{array}$ & Vietnam & USA & Egyéb & Összesen \\
\hline Összes & 177001 & 20122 & 14246 & 30244 & 22741 & 108581 & 372935
\end{tabular}

Ebből a legnagyobb csoportok

\begin{tabular}{lrrrrrrr}
\hline $\begin{array}{l}\text { Szakképzetlen, } \\
\text { gyakornok }\end{array}$ & 10575 & 5240 & 3862 & 7706 & 0 & 43543 & 70926 \\
H-2 & 56875 & 0 & 6525 & 1 & 0 & 1681 & 65082 \\
Külföldi koreai & 33745 & 0 & 1260 & 0 & 4179 & 6433 & 45617
\end{tabular}

Forrás: Number of incoming foreigners by type of visa and citizenship (2015).

Megjegyzés: a Dél-Koreában 37 féle vízum van érvényben, a legtöbb esetében viszonylag kisszámú bevándorlóval.

A harminchét féle vízum közül az A, D, E, F, G és a H típusok szolgálnak a három hónapnál hosszabb ideig terjedő tartózkodásra. Jelenleg a 2007-ben bevezetett Munkalátogató rendszer a legújabb, amely a korábbi elavult gyakornoki rendszereket váltotta fel, miután az 2005-ben megszűnt, adminisztratíve pedig beépült az engedélyezési rendszerbe, így bizonyos értelemben gyakornokok továbbra is vannak. A látogató rendszer az orosz és a kínai koreaiak munkavállalását hivatott megkönnyíteni, így munkaközvetítői díjat sem számít fel igazolt származás esetén, ami pedig 5-10 millió won volt korábban. Ez tehát a H-2 vízum, amely jelenleg a legnagyobb számban kibocsátott típus a külföldi munkaerő körében. A kínai és orosz koreaiak egyszóval előnyt élveznek más országokból bevándorolni szándékozókkal szemben - élő rokont Koreában nem, de nyelvvizsgát fel kell mutatniuk -, de még így is hátrányban vannak más országokban élő koreaiakkal szemben, akiknek az F-4 vízum jár, ami öt évig érvényes, és három év folyamatos tartózkodást, szabad munkavállalást, valamint korlátlan számú ki- és belépést tesz lehetővé (Kim, Hyuk-Rae 2012: 130).

A H-2 vízumot munkaközvetítőkön keresztül lehet igényelni, vagy olyan vállalatoktól közvetlenül is beszerezhető, akik rendelkeznek megfelelő jogosultsággal annak kiadásához. Ők bármikor szabadon válthatnak munkahelyet is, 
ha már elvégezték az előirt képzést, 2009 óta azonban be kell jelenteni azt az Igazságügyi Minisztériumnál. 2007 előtt gyakorlatilag lehetetlen volt a hajdani szovjet tagországokból, Oroszországból vagy Kínából származó koreaiaknak munkát vállalni Koreában ott élő rokon nélkül, nem csoda, ha számuk a rendszer bevezetése előtti 130 ezerről, 2011-re 319 ezerre nőtt (Oh et al. 2012: 39). A Kínából származó koreaiak előnye a nyelvtudásuk révén vitathatatlan, s azt is megmagyarázza, hogy az egyébként is legnagyobb számú, 2 milliós kisebbség miért adja a legtöbb H-2 vízummal munkát vállalót (Kim, Nam-Kook 2014a: 55). Utánuk következnek az engedélyezési rendszeren keresztül érkező, E-9 vízummal rendelkező bevándorlók. 2015-ben mindkét csoport közel ugyanannyian főt tett ki: H-2 vízummal 283 ezren, míg E-9 vízummal 271 ezren tartózkodtak az országban; összesen az 1 millió 143 ezer bevándorló 48\%-át adva (Status of Registered Foreigners).

A maximum 3 éves szerződés nem teszi lehetővé a családtagok beutazását, és újabb szerződés kötésére sincs lehetőség ezalatt, csak annak leteltével lehet további 2 évet hosszabbítani rajta. Ezt a felülről tervezett keretrendszert, amelyhez a helyi önkormányzatok és az NGO-k is csupán alkalmazkodhatnak, a 2007-es Törvény a külföldiek kezeléséröl Koreában szabályozza (Act on the Treatment), Deborah Milly (2014: 141-143.) „vezényelt kormányzás”-nak nevezi központosított jellege miatt. Az 1990-es évek eleje óta nem sikerült a piaci szereplők és a kormány ellentétes érdekeiből koherens migrációs politikát kialakítani, különösen a szakképzetlen bevándorlók esetében valamilyen következetes integrációs programot megvalósítani. A szakképzettek számára továbbra is fennáll a tartós letelepedés lehetősége, de képzettség hiányában a munkaerőt csak irányítani, ellenőrizni, vagy kizárni akarja a kormány (Kim, Nam-Kook 2014b: 51). Mindez ráadásul a civil szféra küzdőterében formálódik, így a nem kormányzati szereplők szerepe különösen felértékelődik. 420 NGO támogatja Koreában a bevándorlók helyzetét ${ }^{2}$ (행정안전부 2011)!

A bevándorlási törvény valójában a szabályozás egy egész készlete, mely mindenre kiterjed, ami kapcsolatban van a külföldiek országba érkezésével, annak elhagyásával, vagy az ott-tartózkodásukkal, sőt bizonyos kérdésekben hatálya az állampolgárokra is kiterjed. Az integrációt a már említett, a külföldiek kezeléséröl szóló törvény szabályozza 2007 óta, beleértve azok emberi jogait, a házasság és multikulturalitás, valamint beilleszkedés kivánalmait és elvárásait. Koreában a külföldi lakosok helyzetének és a migrációnak is sokkal inkább központosított,

\footnotetext{
${ }^{2}$ A kormány 2011-es felmérése szerint összesen 594 civil szervezet foglalkozik a külföldiekkel és bevándorlókkal, ezek közül 132 egyházi intézmény.
} 
mintsem dekoncentrált a szabályozása. Az ügyintézés, a döntéshozatal és általában minden intézmény a minisztériumokhoz tartozik; az 5 évente célkitüzéseket meghatározó alapterveket is az Igazságügyi Miniszter hivatott megalkotni, s ő irányítja az egyeztetést a többi minisztérium és egyéb magas szintű részt vevők, valamint a civil szféra között. A felülről szerveződő rendszer végrehajtása jól működik, 2010-re a törvényt már 223 városban foglalták rendeletbe, ami az iránymutatást elfogadó települések 91,4\%-a (Hwang 2014: 141).

Továbbra is fennáll a diaszpóra pozitív diszkriminatív kezelése abban a tekintetben, hogy azok a kivándorolt koreaiak, vagy akár azok unokái is, akiknek volt korábban koreai állampolgárságuk, jogosultak az F-4 vízumra, amely 2 évig érvényes, utána pedig F-5 vízumra váltható, ami pedig már korlátlan időre szóló tartós tartózkodást biztosít, sőt, szavazati jog is jár vele (F-4 Visa). Az ő számuk nő a leggyorsabban az utóbbi években, ez részben annak köszönhetően, hogy bár a vízum már bármely országból igényelhető, a legnagyobb részüket a fentiek okán még mindig az Amerikából hazatelepülők teszik ki, másfelől viszont a bevándorlási törvény 23. szakasza továbbra is tiltja a szakképzetlen munkát számukra, így tehát ez a szelekciós szempont is tovább él. A helyzetet korrigálandó, a volt szovjet tagországokból hazatelepülni szándékozó koreaiakat külön törvény támogatja, és nem csupán a bevándorlásukat, beilleszkedésüket és állandó tartózkodási engedélyüket támogatja, hanem elrendelte az 1860 és 1945 között kivándorolt családok felkutatását és az érintett országokkal való diplomáciai kapcsolatok fejlesztésének támogatását is. Ez a törvény segíti a befogadó országokban az ottani állampolgárság elnyerését és a koreai kultúrházak, nyelvtanfolyamok létesítését is, így tehát az ugyan nem állítható, hogy egyértelműen csak a hazavándorlást serkenti, de ez utóbbi már kimondott cél még a helyi beilleszkedés támogatása mögött is (Special Act on Support).

\section{VEGYES HÁZASSÁGOK ÉS MULTIKULTURÁLIS PROGRAM}

Az integráció hiányosságaként megmaradt továbbra is az osztályalapú és az etnikai megkülönböztetés, ám az 1990-es években egy olyan jelenség vette kezdetét, ami alapvető változást hozott napjaink koreai bevándorlási és integrációs politikájába. A gazdaság élénkülése, az urbanizáció és a női iskolázottság és foglalkoztatás arányának növekedése (Jones - Shen 2008) hatására a falusi térségekből egyre nagyobb számban költöztek fel a nagyvárosokba fiatal nők munkát vállalni. A folyamat következtében vidéken a nemi arány felborult, mert 
a férfiak nagyobb hányada maradt ott a családi farmergazdaságokat vezetni, s így sokan közülük nem találtak feleséget maguknak. ${ }^{3} \mathrm{~A}$ jelenséget gyorsan érzékelte a piac is, s nyomban szakosodtak házasságközvetítő cégek a feladatra, de a legérdekesebb a jelenségben az, hogy már az 1990-es évek elején a kormány olyan alapokat hozott létre, amik ezeknek a vállalatoknak nyújtottak segitséget (Freeman 2011: 2, Chung - Yoo 2013). Mindazonáltal átfogó szabályozás sokáig nem született, s így a piacon egyfajta szabad verseny alakult ki, amelynek hatására, különösen a 2000-es évek elején robbanásszerüen emelkedett az imént vázolt csatornán keresztül bevándorló nők száma (DeWind et al. 2012: 377). Hogy a problémát orvosolják, az önkormányzatok is kampányt indítottak; ebben az időszakban főként Kínából importáltak feleségeket az egyedül maradt férfiak számára. Évről évre gyarapodott tehát az így érkező menyasszonyok száma, s mivel az urbanizáció ilyetén hatása elsősorban a vidéki településeket érintette, mára ott a legtöbb a vegyes házasság (Hwang 2015: 378).

2010-ig a vegyes házasságok száma gyorsan nőtt, 85\%-uk női bevándorló volt, akiknek a helyzetét sem jogi szabályozás, sem intézményi segítség nem támogatta az állam részéről egészen a 2000-es évekig; a civil szervezetek, különösen a keresztény egyházak viszont már az 1990-es években rengeteg egyesületet hoztak létre e célból (Kim, Hyuk-Rae 2012: 133). Az első évtizedben a szabályozás hiánya azzal járt, hogy a beházasodó felek azonnal állampolgársághoz jutottak, valamint további két vízumhoz, ami a feleség szüleinek adott lehetőséget, hogy Koreában tartózkodjanak. Ez idő tájt azonban rengeteg visszaélés történt a kormány által gálánsan, vagy egyáltalán nem kezelt helyzettel. Egyrészt sokan csupán érdekből kötöttek házasságot, s némi, a férjnek adott fizetség ellenében hamarosan el is váltak. Másfelől az is sokszor előfordult, hogy a külföldi menyasszonyok a férjet is kijátszották, s a házasság után egyszerủen eltủntek, vagy beadták a válókeresetet (Freeman 2005: 93, Freeman 2011: 172).

Többek közt ez a tarthatatlan helyzet vezetett az 1997-es Állampolgársági törvény szigorításához: azokhoz az előirásokhoz, amelyek megkövetelték a Kínából érkező nőktől a nem házas állapot bizonyitását, a megkötött házasság regisztrációját és előirrták a 2 év várakozási időt az állampolgárság igényléséhez (Hwang 2015: 381, Lee 2008: 121). Nem voltak jogaik, nem dolgozhattak, nem fértek hozzá a jóléti szolgáltatásokhoz és azonnali deportálás várt rájuk, ha megszöktek az

\footnotetext{
${ }^{3}$ A nemi arány szükségszerüen a nagyvárosokban is megváltozott, ám az ott karriert épitő nők nagyobb hányada nem kivánt - legalábbis egy ideig - férjhez menni.
} 
előirt 2 év türelmi időn belül. Az igazsághoz azonban az is hozzátartozik, hogy a férjek sok esetben valóban visszaéltek a hatalmukkal, s a feleségek menekülése így indokolt volt (윤형숙 2005). Az igazi problémát éppen az okozta, hogy még a számtalan elvégzett kutatás is nehezen választotta szét a valós bántalmazásból származó szociális beilleszkedési és pszichés problémákat a bevándorlás és beilleszkedés nehézségeiből általánosan adódó negatív érzetektől (정남옥 - 이명하 2010, Panuncio - Bae 2012: 63).

4. táblázat: A házassági célból bevándorlók számának alakulása Dél-Koreában nemzetiség szerint, 2002-2015 között

Changes in the number of marriage migrants in South Korea by nationality, between 2002-2005

\begin{tabular}{|c|c|c|c|c|c|c|c|c|}
\hline Év & Kína & $\begin{array}{l}\text { Koreai- } \\
\text { kínai }\end{array}$ & Vietnam & Japán & $\begin{array}{c}\text { Fülöp- } \\
\text { szigetek }\end{array}$ & $\begin{array}{l}\text { Kam- } \\
\text { bodzsa }\end{array}$ & Egyéb & Összes \\
\hline 2002 & 3022 & 10055 & 455 & 4147 & 2518 & 4 & 3213 & 23414 \\
\hline 2003 & 5177 & 17380 & 1767 & 6583 & 4227 & 17 & 6277 & 41428 \\
\hline 2004 & 8363 & 24553 & 3717 & 7544 & 3738 & 73 & 8013 & 56001 \\
\hline 2005 & 14658 & 30602 & 7449 & 7731 & 3865 & 206 & 9665 & 74176 \\
\hline 2006 & 20377 & 35528 & 14820 & 6539 & 4263 & 457 & 11143 & 93127 \\
\hline 2007 & 26489 & 36401 & 21604 & 5817 & 4978 & 1919 & 12653 & 109861 \\
\hline 2008 & 32020 & 35520 & 27084 & 5216 & 5777 & 2683 & 13873 & 122173 \\
\hline 2009 & 33426 & 32566 & 30173 & 5074 & 6321 & 3230 & 14297 & 125087 \\
\hline 2010 & 35023 & 31664 & 35355 & 10451 & 7476 & 4195 & 17490 & 141654 \\
\hline 2012 & 35140 & 27895 & 39352 & 11746 & 9611 & 4541 & 20213 & 148498 \\
\hline 2013 & 36126 & 26274 & 39854 & 12220 & 10383 & 4650 & 21358 & 150865 \\
\hline 2014 & 36059 & 24604 & 39725 & 12603 & 11052 & 4618 & 22333 & 150994 \\
\hline 2015 & 35658 & 23130 & 40847 & 12861 & 11367 & 4555 & 23190 & 151608 \\
\hline
\end{tabular}

Forrás: Status of Marriage Migrant by Nationality (2015). 
A helyzet javitására a kormány 2006-tól egyre több támogató programot hirdetett meg a házasság céljából bevándorló nők számára, a multikulturális társadalommal kapcsolatos diskurzus is élénkebbé vált (Seol - Skrentny 2009b, Kim - Kang 2007), de leginkább azt a hatását érdemes kiemelni, amelynek következtében a bevándorlási politika egyre nagyobb hangsúlyt fektetett az integrációra. Ez utóbbinak ma is az egyik központi eleme a vegyes házasságokban élő külföldiek és gyermekeik beilleszkedése (Lee 2008).

Az 1990-es évek óta a legtöbb menyasszony Kinából érkező koreai nő, ám a 2000-es évek elejétől a kínai és főként a délkelet-ázsiai nők aránya egyre nő. Ez egyben az egyik legnagyobb törésvonal is közöttük, ugyanis annak ellenére, hogy a kormány jelentős erőfeszítéseket tesz annak érdekében, hogy a külföldi feleségek a koreai nyelvet elsajátítsák, jelenleg még mindig annak elmaradása az egyik legfontosabb tényező, ami meggátolja őket abban, hogy a munkaerőpiacon integrálódni tudjanak. A másik fontos összetevő a gyermekfelügyeletet ellátó rokonok hiánya, ami a kisgyermekes anyák számára meglehetősen jelentős korlátozó tényező a munkavállalás terén (Lee, Hye-Kyung 2013a: 222). A többségük ennek megfelelően marginális pozíciókban, alkalmi és részállásokban tud csak munkát vállalni, szemben a hasonló helyzetủ koreai nők többségével, akik többnyire teljes állásban vállalnak munkát.

A jelenség hátterében számtalan összetevő áll, amik közül néhány fontosabbat érdemes megemlíteni. Először is, habár a női iskolázottság és foglalkoztatás növekedése a közvetlen közrejátszó ok a feleségimport megjelenésében, a változásokkal az is együtt járt, hogy az ily módon modernizálódó felfogású koreai nők egyre kevésbé akarják a tradicionális szerepeket betölteni a családokban. Ez is közrejátszik abban, hogy sokan már meg sem próbálnak feleséget találni Koreában, gondolván, hogy az elmaradottabb országok ázsiai feleségei jobban őrzik a hagyományos szemléletet, s így jobb feleségekké vagy menyekké válnak majd (Bélanger et al. 2010: 1112). Az alacsonyabban iskolázott férfiak számára persze már az is elég ok, hogy a családon belüli szerepek egy emancipált koreai feleséggel felborulnának, ami az alacsonyan iskolázottabb délkelet-ázsiai menyasszonyok iránti igényt növeli (Kim et al. 2014: 130). Ugyanakkor az önkormányzatok is érdekeltté váltak az egyes települések elnéptelenedése miatt, s rendszeres támogatást kezdtek nyújtani a fiúgyermekes családoknak, hogy feleséget hozathassanak maguknak a házasságközvetítő cégeken keresztül. Ez utóbbi pedig jelentős szerepet játszott a partnerközvetítő iparág hazai és külföldi fellendülésében is (Wang - Chang 2002). S végül azt sem szabad elfelejteni, hogy a globális etnikai migrációs hálózatok kiépülése is nagyban hozzájárul a jelenség intézményesüléséhez. Falusi térségekben a jelenség normává vált, s így mára 
egyszerübben értelmezve is relatíve depriválttá válik az, aki nem hoz magának feleséget külföldről, de még az is elképzelhető, hogy egy migrációs rendszer jött létre így.

Mindez tehát csupán a gazdasági szereplőket, az önkormányzatokat és természetesen az NGO-kat érdekelte egészen 2005-ig, amikor tizenhat kongresszusi tag benyújtott egy törvénytervezetet, miszerint a házasságközvetítő ügynökségeket szabályozni kellene. Ezt követően az Egészségügyi és Jóléti Minisztérium felkérésére nagyszabású felmérést folytattak le országszerte. Ez képezte az alapját annak, hogy 2006. április 26-án a kormány bejelentett egy tervet, amit Lee (2008: 114, Skrentny - Lee 2014: 142) a Nagy Tervnek hív. Ez egy átfogó integrációs program, amely számos szolgáltatás bevezetését kezdeményezi, elsősorban természetesen a nyelvoktatás fejlesztését, a koreai kultúra oktatását és a munkahelyi tréningeket. A tervet követően kormányzati alapok létesültek annak támogatására. Hozzá kell tenni azonban, hogy a házassági bevándorlás ilyetén előtérbe helyezése az ország irányítói számára azt is jelenti, hogy sem a vállalatok, sem a szakszervezetek, de még a közvélemény sem foglalkozik annyit a bevándorló munkaerővel, mint korábban, így a társadalmi feszültségeket felváltja az együttérzés és a szimpátia.

Nőpolitikából időközben családpolitika lett, így az individuumból ismét feleség és meny vált (Lee 2008: 120). A bevándorló házastársak mindenesetre 2005-től jogosulttá váltak bármely területen munkát vállalni, s 2 év tartózkodás után állampolgárságot igényelni, habár ez utóbbi igen hosszadalmas procedúra, s általában másfél év, mire a jelentkező eljut az interjúig. Az is nehezíti a munkavállalást, hogy a férjek családja többnyire nem szívesen látja, hogy a háztartáson kívül másutt is dolgozzon a friss feleség, különösen a házasság első éveiben, s leginkább, ha gyerek is születik. A kérdés pedig 2005-re igen nagy jelentőségűvé nőtt, ugyanis a vidéki férfiaknak már a 36\%-a külföldi feleséggel élt együtt addigra (Lee 2009), s ez országos szinten is 12\% körüli értéket jelent.

2006-ban két programot is hirdettek, amelyek A Női bevándorlók családjainak társadalmi beilleszkedésének segítése, valamint a Kevertvérüeket és bevándorlókat segítő terv neveket kapták, mindkettőt azonos elnevezésű törvény szabályozta. Ezek keretében szabályozták az ügynökségek felelősségét és működését, illetve igyekeztek kizárni azt, hogy embercsempészetre használják a házasságközvetítést. Az új helyzet a férjeket is megakadályozta abban, hogy különféle módokon korlátozzák a feleségeik jogait, s egyben megkönnyítette az utóbbiak számára, hogy elváljanak. Magát az állampolgársági eljárást is igyekezett leegyszerűsíteni, s olyan, külföldön kötött, illegális 
házasságokat is elismert, amit korábban nem. Oktatás a gyermekeknek, információ az anyáknak és általános jóléti szolgáltatások is mind részét képezték a programnak. Mindezekre nyomós okok voltak, hiszen számtalan botrány kísérte az események fejlődését a megelőző években, így pl. olyan hirdetések, amelyek „Menyasszony-garanciát” ígértek, vagyis azt, hogy visszahozzák a férjnek a menyasszonyát, ha az megszökne (Lee 2008: 118, Lee, Hye-kyung 2013b: 300). Mindezeket a fent említett két törvényen kívül a 2007-ben elfogadott, A multikulturális családokat segítő törvény is kiegészítette (Kim, Nora Hui-Jung 2013b: 109).

A Nagy Terv évében elkészült a külföldiek kezeléséről szóló, már említett törvény is (Lee, Hye-kyung 2013b: 293). Mindezen események sodrában már egy átfogóbb tervezés született meg 2008-ban: az Első alapterv a bevándorlási politika számára (2008-2012), amely alapvetően egy jóléti program, ami támogatásból, biztositásból és egyéb szolgáltatásokból áll, Koreába házasodó külföldi feleségek és külföldi dolgozók részére (Kim, Anna 2016: 90). Gyakorlatilag egy teljes biztositási rendszerről van szó, ami külön kiemeli a multikulturális családok támogatását, beleértve az egyedülálló szülőket, a nyelvoktatást, valamint a foglalkoztatási támogatást. A program kimondott célja az ellenőrzés-orientált politika helyett a stratégiai nyitás a bevándorlás felé, s ezen keresztül a nemzeti versenyképesség fokozása, így tehát eszmeiségében kötődik a tehetség és humántőke-import céljaihoz, egyúttal azonban olyan társadalmi integrációt igyekszik megvalósítani, ami nem csupán intézményes elemekből áll. Ez utóbbiak természetesen mind annak alapelemei, sőt, a bevándorlási és határőrizeti jogszabályok, továbbá a bevándorlók emberi jogainak fejlesztése is, ám távlati célja egy mindezeknél átfogóbb és mélyrehatóbb beilleszkedés segítése (The First Basic Plan).

A bevándorlók beilleszkedésére szánt költségvetési keret évről évre nő, 2009-ben létrejött a Multikulturális Családpolitikai Bizottság a miniszterelnök vezetésével (Kim, Sookyung 2015: 57), amely akcióterveket dolgoz ki a vegyes házasságok támogatására. Sokan persze vitatják az egyértelmű hatást, s kulturális paternalizmusról vagy kulturális fetisizmusról beszélnek, azt állitva, hogy a multikulturális program sokkal inkább felerősíti az etno-kulturális hierarchiát, minthogy elsimítaná azt (Kim, Joon K. 2011: 1583). Így tehát a kormány szándékával szemben az is felvethető, miszerint a multikulturális kifejezés egész egyszerüen a kulturális vagy etnikai másság szinonimájává vált Koreában (Schubert - Lee - Lee 2015: 239). A legszebb az egészben, hogy 2 évre rá hogy a kormány meghirdette multikulturális politikáját, a lakosság nagy része már el is hitte, hogy ilyen társa- 
dalomban él. Mindezt annak ellenére, hogy a bevándorlók száma 2016 júniusában is csupán 2001828 fő volt az országban (출입국 - 외국인정책본부), s annak ellenére is, hogy a nemzetközi szervezetek nem győzik napjainkban sem újra és újra figyelmeztetni a dél-koreai vezetést, hogy hagyjon fel a bevándorlókat kezelő diszkriminatív politikai gyakorlatával. 2008-ban pl. az Amnesty International (2008: 3) bírálta a Koreában zajló diszkriminatív munkaerő-piaci gyakorlatot.

A bevándorlási politika helyzete ellentmondásos. A családok beilleszkedését segítő törvény és az állampolgársági törvény is sokat tett ez ügyben, de továbbra is megkülönböztető. Az előbbi pl. továbbra is tartalmazza azt a kitételt, hogy az - egyébként még a dél-koreai állampolgároknak sem járó - juttatások csupán a bevándorló nőknek elérhetőek, s nekik is csak akkor, ha már megházasodtak. Másfelől a gyermekekről csak akkor vesz tudomást, ha azok koreai apától születtek. Miközben egyik kezével sokat nyújt a kormány a bevándorlóknak, időnként még többet is, mint szükséges, a másikkal továbbra is fenntartja a nemzet egységességének diszkriminatív, etnocentrikus, nacionalista és asszimilációs logikáját (Kim, Sookyung 2015: 64-65). A 2007-es törvény a külföldiek kezeléséről előírja, hogy ötéves tervek készüljenek a bevándorlás kezelésére, így tehát a Multikulturális családpolitikai bizottság 2013-ban meghirdette a második Alaptervet a bevándorlási politikára (The 2nd Basic Plan). Az öt célkitűzés mindegyike, amelyet magában foglal, további 2-3 akciótervet tartalmaz. Mindezek közül az első a gazdaságélénkítés és a tehetségprogram, mely lényegében az egész dél-koreai bevándorlási politikának az egyetlen, a kezdetektől fogva koherens eleme. A második pont a bevándorlók integrálása a koreai értékek megőrzésével, amelyben külön hangsúlyt kap a bevándorlók saját felelőssége, mintegy kiegyensúlyozandó az első tervben még olyannyira hangsúlyozott nyitottságot. A harmadik a diszkrimináció megelőzése és a kulturális különbségek elfogadásának elősegítése, a negyedik a biztonságos és szabályos társadalom kialakítása, amely a szabályozás szigorítását célozza, s végül az ötödik a küldő országokkal való nemzetközi együttmüködés élénkítését tervezi, külön akciótervvel a koreai diaszpórával való kapcsolat erősítésére (Lee, June 2013).

Annak ellenére, hogy milyen sok vita folyt a második tervet megelőzően arról, hogyan értelmezendő maga a multikulturális kifejezés a migrációs politika szemszögéből nézve, a megközelítés pontosabb definiálását mégis elmulasztotta az újabb ötéves terv. Annyi azonban egyértelműen kiderül, hogy a szándék elsősorban a bevándorló feleségek beilleszkedésére irányul, s ez egybecseng azzal, hogy a korábbi terv költségvetésének 95\%-át is erre költötték 
el (The 2nd Basic Plan: 16). Az is gyakran felvetett probléma, hogy a multikulturális program kizárólag a külföldiekre irányul, azok beilleszkedését segítik a felépített központok, a nyelv- és kulturális tanfolyamok, s ezzel sokkal inkább egyfajta asszimilációs folyamatot erősítenek, mintsem a multikulturális társadalom elfogadását. A vegyes házasságok növekedése e század elejétől tehát összefüggésben áll a „diszkriminatív” hierarchiák intézményi támogatása miatt is.

A választóvonal továbbra is él koreai és idegen között, s az is világos, hogy az utóbbiak sohasem lehetnek igazi koreaiak (Shen 2016: 8, Kim, Nora Hui-Jung 2015: 729, Watson 2010). Az is egyértelműen kiviláglik az alaptervekből, hogy a gazdasági szempont felülírja a migrációs politikai célokat. Ez érződik még a külföldi professzorok helyzetén és természetesen a befektetői vízumok esetében is. Ez utóbbiak talán leglátványosabb formája a 2010-ben bevezetett ingatlanbefektetői vízum, amit Csedzsu-sziget kormányzata hirdetett meg, s ami abban az esetben kínálja az F-2 vízumot, ha legalább félmillió dollárért vásárol valaki ingatlant (Over 1,000 Foreigners).

\section{ÖSSZEGZÉS}

A félsziget déli állama földrajzilag két végpont között helyezkedik el: az egyik a bevándorlást és beilleszkedést is egyöntetüen korlátozó Japán, a másik vegyes képet mutató térség, Délkelet-Ázsia, amelynek országai többnyire piaci alapon müködő migrációs rendszereket működtetnek. De átmeneti az ország helyzete saját fejlődését tekintve is. A hagyományosan nemzetállami keretek között formálódó bevándorlási politika olyan népesedési problémákkal szembesült, mint általában a modern posztindusztriális országok: az elöregedő korszerkezet, a csökkenő termékenység és népesség, a hiányszakmák megjelenése és az ebből következő gazdasági gondok, mint az eltartóképesség csökkenése, vagy a szociális rendszer rentabilitásának ellehetetlenülése.

Dél-Korea úgy tűnik, hogy képes változtatni hagyományos elzárkózásán, és tudatos lépéseket tenni mind a bevándorlás élénkítése, a már meglévő csatornák intézményesítése és a bevándorlók integrálása érdekében is. A megoldások sokszor még nehezen találják meg a központi akarat és a társadalom civil szférája közötti összhangot, s a multikulturális társadalom építése túl gyors és meglehetősen kevéssé spontán, ám több szempontból is 
előremutató népesedéspolitikai átalakulás kíséri az ugyancsak rohamos demográfiai folyamatokat. Ezt a folyamatot tovább bonyolítja, hogy a nemzeti homogenitás egyben tradicionális értékrendszerhez kötődik, változása lassú, miközben a globális hálózatokba való integrálódás érinti a bevándorlást is. Dél-Koreában pl. az atipikus foglalkoztatás nem csak a bevándorlók esetében nőtt, s mindez egyszerre vezet gyors társadalmi átalakuláshoz belső és külső okok miatt is.

Mindez igen jelentős változásokat is jelenthet a jövőben: a délkelet-ázsiai országokból érkező egyre nagyobb számú bevándorló, s a beilleszkedésüket támogató politikák hosszú távon egy migrációs folyosó kialakulásához is vezethetnek, hacsak máris nem beszélhetünk erről. Mindez már most megelőlegezi egy jóval nagyobb számú bevándorló okozta, s egy, a multikulturális együttélésből fakadó feszültségek növekedésének lehetőségét, sőt, akár a térség többi fejlett országára is hatást gyakorolhat egy esetleges munkaerő-piaci túlkínálattal. Egy ilyen szcenárió akár Kelet-Ázsia bevándorlási piacának teljes átalakulását is előidézheti, akár azok átstrukturálódása, akár a szigorodó politikák révén. Kínában pl. egy olyan demográfiai átalakulás kezdődött el, aminek következtében a vidék már nem sokáig lesz kimeríthetetlen forrása a munkaerőnek. 2003-ban, először a történelemben, ezt már megtapasztalta az ország (Cai - Du - Wang 2009). A gyorsan növekvő és egyre inkább a szolgáltatás által dominált gazdaság, valamint az urbanizáció következményeképpen a közeljövőben ott is átalakulás várható a migráció jellegében, s a bevándorlás beindulásában Dél-Korea jelentős szerepet játszhat majd. 


\section{IRODALOM}

About KOISEN. Ministry of Science, ICT and Future Planning. http://www.kosen21.org/ about/aboutKosen.do Letöltve: 2016. augusztus 13.

Act on Foreign Workers' Employment. Act No. 6967, Republic of Korea. Aug. 16, 2003. http://www.koilaf.org/KFeng/engLaborlaw/laborlaw/ACTONFOREIGNWORKERS'.pdf Letöltve: 2016. augusztus 15.

Act on the Immigration and Legal Status of Overseas Koreans. Statutes of the Republic of Korea. http://elaw.klri.re.kr/eng_mobile/viewer.do?hseq=29311\&type=part\&key=44 Letöltve: 2016. augusztus 12.

Act on the Treatment of Foreigners in Korea. Act No. 8442 May. 17. 2007. Amended by Act No. 21214. Korea Ministry of Government Legislation. Dec. 31. 2008.

Amnesty International 2008: Republic of Korea. Submission to the UN, Universal Periodic Review Second session of the UPR Working Group, 5-16 May 200825 January 2008. Al Index: ASA 25/002/2008.

Armstrong, Charles K. 2007: Globalizing Regions. Korea. Routledge, New York.

Armstrong, Charles K. (ed.) 2002: Korean society: civil society, democracy and the state. Routledge, Abingdon.

Bélanger, Danièle - Hye-Kyung Lee - Hong-Zen Wang 2010: Ethnic Diversity and Statistics in East Asia: 'Foreign Brides' Surveys in Taiwan and South Korea. Ethnic and Racial Studies, 33(6), 1108-1130.

Boll, Alfred Michael 2007: Multiple Nationality And International Law. Martinus Nijhoff Publishers, Leiden.

Brubaker, Rogers W. 1990: Immigration, Citizenship, and the Nation-State in France and Germany. International Sociology, 5(4), 380-381.

Cai, Fang -Yang, Du - Wang, Meiyan 2009: Migration and Labor Mobility in China. Human Development Research Paper, 2009/09: United Nations Development Programme.

Choi, Inbom 2003: Korean Diaspora in the Making: Its Current Status and Impact on the Korean Economy. In Choi, Inbom - C. Fred Bergsten (eds.): The Korean Diaspora in the World Economy. Institute for International Economics, Washington, 9-29.

Chung, Grace H. - Joan P. Yoo 2013: Using the Multicultural Family Support Centers and Adjustment Among Interethnic and Interracial Families in South Korea. Family Relations, 62(1), 241-253.

CIA World Factbook 2016: Korea, South. https://www.cia.gov/library/publications/theworld-factbook/geos/ks.html Letöltve: 2016. augusztus 12.

D-10 (Job Seeking) Visa. Ministry of Foreign Affairs, Republic of Korea. http://gbr.mofa. go.kr Letöltve: 2016. augusztus 17.

Delissen, Alain - Ceuster, Koen de - Gelézeau, Valérie 2013: De-bordering Korea: tangible and intangible legacies of the sunshine policy. Routledge, London.

DeWind, Josh - Eun Mee Kim - Ronald Skeldon - In-Jin Yoon 2012: Korean Development and Migration. Journal of Ethnic and Migration Studies, 38(3), 371-388.

Diener, Alexander 2006: Homeland as Social Construct: Territorialization among Kazakhstan's Germans and Koreans. Nationalities Papers, 34(2), 201-235. 
Employment and Labor Minister holds meetingwith ambassadors of countries sending workers to Korea under Employment Permit System. June 26, 2012. http://www.moel. go.kr/english/poli/poliNewsnews_view.jsp?idx=931 Letöltve: 2016. augusztus 15.

Employment Permit System. Happy Return Program. Ministry of Employment and Labor. https://www.eps.go.kr/en/supp/supp_02.jsp Letöltve: 2016. augusztus 15.

F-4 (People of Korean Heritage) Visa. Ministry of Foreign Affairs, Republic of Korea. http://gbr.mofa.go.kr Letöltve: 2016. augusztus 17.

Freeman, Caren 2005: Marrying up and marrying down: The paradoxes of marital mobility for Chosonjok brides in South Korea. In Constable, Nicole (ed.): Cross-Border Marriages: Gender and Mobility in Transnational Asia. University of Pennsylvania Press, Philadelphia, 80-100.

Freeman, Caren 2011: Making and faking kinship: marriage and labor migration between China and South Korea. Cornell University Press, Ithaca.

Fumagalli, Matteo 2006: Identity and interests in South Korea's policy towards Central Asia. In Proceedings of the World Congress of Korean Studies. Vol 3. Academy of Korean Studies, Soul, 183-191.

Fumagalli, Matteo 2012: South Korea's Engagement of Central Asia from the End of the Cold War to Lee Myung-Bak's New Asia Initiative. Journal of Northeast Asia History, 9(2), 69-97.

Gelb, Michael 1995: An Early Soviet Ethnic Deportation: The Far-Eastern Koreans. Russian Review, 54(3), 389-412.

Hahn, Chin Hee - Yong Seok Choi 2006: The Effects of Temporary Foreign Worker Program in Korea: Overview and Empirical Assessment. Paper presented at the Korea and the World Economy and the World Economy Conference, Seoul, KOR, July 7-8, 2006. $1-63$.

Hill, Richard Child - Kim, June Woo 2000: Global Cities and Developmental States: New York, Tokyo and Seoul. Urban Studies, 37(12), 2167-2195.

Human Resources Development Service of Korea. http://www.hrdkorea.or.kr/ENG Letöltve: 2016. augusztus 16.

Huttenbach, Henry R 1993: The Soviet Koreans: Products of Russo-Japanese Imperial Rivalry. Central Asian Survey, 12(1), 59-69.

Hwang, Eui-Gak 2010: The Search for a Unified Korea: Political and Economic Implications. Springer, New York.

Hwang, Jung-Mee 2014: Local Citizenship and Policy Agenda for 'Foreign Residents'in East Asia. In Kim, Nam-Kook (ed.): Multicultural Challenges and Sustainable Democracy in Europe and East Asia. Palgrave Macmillan, New York, 129-152.

Hwang, Min-Chul 2015: Exploring marriage migrants' citizenship acquisition in South Korea. Asian and Pacific Migration Journal, 24(3), 376-402.

Immigration Act. Statutes of the Republic of Korea. http://elaw.klri.re.kr/eng_mobile/ viewer.do?hseq=29332\&type=new\&key= Letöltve: 2016. augusztus 17.

The 2nd Basic Plan for Immigration Policy 2013-2017. Immigration Policy Commission. Seoul, Korea Immigration Service, Ministry of Justice.

Jones, Gavin - Hsiu-Hua Shen 2008: International marriage in East and Southeast Asia: trends and research emphases. Citizenship Studies, 12(1), 9-25. 
Kho, Songmoo 1987: Koreans in Soviet Central Asia. Studia Orientalia, Helsinki.

Kim, Anna 2016: Welfare policies and budget allocation for migrants in South Korea. Asian and Pacific Migration Journal, 25(1), 85-96.

Kim, Eun Mee - Jean S. Kang 2007: Seoul as a global city with ethnic villages. Korea Journal, 47(4), 64-99.

Kim, Hansung - Sun Young Lee - In Hee Choi 2014: Employment and Poverty Status of Female Marriage Immigrants in South Korea. Asian and Pacific Migration Journal, 23(2), 129-154.

Kim, Hyuk-Rae 2012: State-centric to Contested Social Governance in Korea: Shifting Power. Routledge, London.

Kim, II-Soo 1981: New Urban Immigrants: The Korean Community in New York. Princeton University Press, Princeton.

Kim, Joon K. 2011: The politics of culture in multicultural Korea. Journal of Ethnic and Migration Studies, 37(10), 1583-1604.

Kim, Min-hyung 2016: South Korea's China Policy, Evolving Sino-ROK Relations, and Their Implications for East Asian Security. Pacific Focus, 31(1), 56-78.

Kim, Nam-Kook 2014a: Multicultural Challenges in Korea: Liberal Democracy Thesis vs. State Initiated Multiculturalism. In Kim, Nam-Kook (ed.): Multicultural challenges and redefining identity in East Asia. Ashgate, Farnham, 45-71.

Kim, Nam-Kook 2014b: The Migrant Workers' Movement in the Democratic Consolidation of Korea. In Kim, Nam-Kook (ed.): Multicultural challenges and sustainable democracy in Europe and East Asia. Palgrave Macmillan, New York, 37-59.

Kim, Nora Hui-Jung 2013: Selective State Response and Ethnic Minority Incorporation: the South Korean Case. In Lai, Ah Eng - Francis Leo Collins - Brenda S. A. Yeoh (eds.): Migration and Diversity in Asian Contexts. Institute of Southeast Asian Studies, Singapore, 107-130.

Kim, Nora Hui-Jung 2015: The Retreat of Multiculturalism? Explainingthe South Korean Exception. American Behavioral Scientist, 59(6), 727-746.

Kim, Richard S. 2011: The Quest for Statehood: Korean Immigrant Nationalism and U.S. Sovereignty, 1905-1945. Oxford University Press, Oxford.

Kim, Soojin 2014: Reforming Korea's Migration Policy. International Journal of Knowledge and Innovation in Business, 1(1), 21-36.

Kim, Sookyung 2015: Soft talk, hardrealities: Multiculturalism as the South Korean government's decoupled response to international migration. Asian and Pacific Migration Journal, 24(1), 51-78.

Kim, Sungmoon 2007: Liberal Nationalism and Responsible Citizenship in South Korea. Citizenship Studies, 11(5), 449-463.

Koudela, Pál 2015: National Identity and Social Resilience in the Case of South Korea. Asia-Pacific Social Science Review, 15(2), 159-167.

Law No. 16 of 1948, Nationality Act (last amended 2010), Republic of Korea. 20 December 1948. http://www.refworld.org/docid/3fc1d8ca2.html Letöltve: 2016. augusztus 12.

Lee, Tae-hoon 2010: Dual Citizenship to Be Allowed. The Korea Times, April 21, 2010. http://www.koreatimes.co.kr/www/news/nation/2011/04/116_64629.html Letöltve: 2016. augusztus 12. 
Lee, Choongbae - Michael J. Bradshaw 1997: South Korean Economic Relations with Russia. Post-Soviet Geography and Economics, 38(8), 461-477.

Lee, Hye-Kyung 2005: The Korean Diaspora and Its Impact on Korea's Development. Asian and Pacific Migration Journal, 14(1-2), 149-168.

Lee, Hye-Kyung 2008: International Marriage and the State in South Korea: Focusing on Governmental Policy. Citizenship Studies, 12(1), 107-123.

Lee, Hye-Kyung 2009: Cross-border marriages between Korean men and migrant women and their marital satisfaction. In Wang, Hong-Zen - Hsing-Huan Michael Hsiao (eds.): Cross-Border Marriages with Asian Characteristics. Academia Sinica, Taipei, 61-89.

Lee, Hye-Kyung 2013a: Employment and life satisfaction among female marriage migrants in South Korea. Asian and Pacific Migration Journal, 22(2), 199-230.

Lee, Hye-kyung 2013b: The Role of Multicultural Families in South Korean Immigration Policy. In Emiko, Ochiai - Aoyama Kaoru (eds.): Asian women and intimate work. Brill, Leiden, 289-313.

Lee, Jeanyoung 2002: Korea's Policy for Ethnic Koreans Overseas. Korea Focus, 11(4), http://www.koreafocus.or.kr/design1/layout/content_print.asp?group_id=411 Letöltve: 2016. augusztus 12.

Lee, June 2013: Migration policy development in the Republic of Korea: A brief review of the Second Basic Plan for Immigration Policy (2013-2017). Migration Policy Practice, 3(2), 22-25.

Lee, Kyu Young 2016: Korea's Migration Policy and its System. In Stüwe, Klaus - Eveline Hermannseder (eds.): Migration und Integration als transnationale Herausforderung Perspektiven aus Deutschland und Korea. Springer, Wiesbaden, 3-25.

Lee, Yu-sup 2016: 15th World Korean Business Convention to open on Sep 27 in Korea. Pulse, July 7, 2016. http://pulsenews.co.kr/view.php?sc=30800022\&year=2016\& no=488492 Letöltve: 2016. augusztus 12.

Levin, Norman D. 1999: The shape of Korea's future: South Korean attitudes toward unification and long-term security issues. Rand, Santa Monica.

Lu, Melody Chia-Wen 2016: Examining Labour Migration Regimes in East Asia: Appearance and Technique of Control in Taiwan. In Mantu, Sandra - Elspeth Guild (eds.): Constructing and Imagining Labour Migration: Perspectives of Control from Five Continents. Routledge, London, 87-109.

Martin, Philip 2013: The Global Challange of Managing Migration. Population Bulletin, 68(2), 2-18.

Martin, Terry 2001: The Affirmative Action Empire: Nations and Nationalism in the Soviet Union, 1923-1939. Cornell University Press, Ithaca, 335-343.

McKeown, Adam 2004: Global Migration, 1846-1940. Journal of World History, 15(2), 155-189.

Meyers, Eytan 2000: Theories of International Immigration Policy - A Comparative Analysis. International Migration Review, 34(4), 1245-1282.

Milly, Deborah J. 2014: New Policies for New Residents: Immigrants, Advocacy, and Governance in Japan and Beyond. Cornell University Press, Ithaca, 141-143.

Moon, Katharine H. S. 2000: Strangers in the Midst of Globalization: Migrant Workers and Korean Nationalism. In Kim, Samuel S. (ed.): Korea's Globalization. Cambridge University Press, Cambridge, 147-169. 
Mundy, Simon 2013: Korea struggles to take in foreign workers. Financial Times, September 17, 2013. http://www.ft.com/cms/s/0/afcdefd4-1c1c-11e3-b67800144feab7de.htm|\#axzz4HQMRwSGt Letöltve: 2016. augusztus 15.

Number of incoming foreigners by type of visa and citizenship. Ministry of Justice, Statistics of Registered Foreigners, Seoul. 2015.

Oh, Jung-Eun - Dong Kwan Kang - Julia Jiwon Shin - Sang-lim Lee - Seung Bok Lee - Kiseon Chung 2012: Migration Profile of the Republic of Korea. The Migration Research and Training Centre of the International Organization for Migration, Gyeonggi-do.

Over 1,000 Foreigners Buy Jeju Property, Get Residency. ChosunMedia, The Chosunilbo. January 27, 2015. http://english.chosun.com/site/data/html_ dir/2015/01/27/2015012701718.html Letöltve: 2016. augusztus 21.

Overseas Koreans Foundation. http://www.okf.or.kr/portal/OkfMainView.do Letöltve: 2016. augusztus 12.

Overseas Koreans Foundation. Ministry of Foreign Affairs, Republic of Korea. http://www. mofa.go.kr/ENG/about/Study/OKF/index.jsp?menu=m_70_70_30 Letöltve: 2016. augusztus 12.

Panuncio, Rosel L. - Jeongyee Bae 2012: The Adjusting Process of Foreign Wives Married to Korean Husbands. Journal of Korean Academy of Psychiatric and Mental Health Nursing, 21(1), 55-66.

Park, Jung-Sun - Paul Y. Chang 2005: Contention in the construction of a global Korean community: The case of the Overseas Korean Act. Journal of Korean Studies, 10(1), $1-27$.

Park, Jung-Wee 2012: Demographic profile of Koreans in Canada. In Noh, Samuel - Ann H. Kim - Marianne S. Noh (eds.): Korean Immigrants in Canada: Perspectives on Migration, Integration and the Family. University of Toronto Press, Toronto, 28-49.

Park, Sincha 2014: Who Benefits from Dual Citizenship? The New Nationality Law and Multicultural Future of South Korea. In Shimizu, Kosuke - William S. Bradley (eds.): Multiculturalism and Conflict. Reconciliation in the Asia-Pacific Migration, Language, and Politics. Palgrave Macmillan, New York, 190-213.

Pohl, Otto J. 1999: Ethnic cleansing in the USSR, 1937-1949. Greenwood Press, Santa Barbara.

Pollack, Jonathan D. - Chung, Min Lee 1999: Preparing for Korean unification: scenarios \& implications. Rand, Santa Monica.

Renzaho, Andre M. N. 2016: Migration challenges and health policy in South Korea. In Renzaho, Andre M. N. (ed.): Globalisation, Migration and Health: Challenges and Opportunities. Imperial College Press, London, 427-479.

Rozman, Gilbert 2006: Regionalism in Northeast Asia: Korea's Return to Center Stage. In Armstrong, Charles K. - Gilbert Rozman - Samuel S. Kim - Stephen Kotkin (eds.): Korea at the center: dynamics of regionalism in Northeast Asia. M. E. Sharpe, Armonk, 151-166.

Schubert, Amelia L. - Lee Youngmin - Lee Hyun-Uk 2015: Reproducing hybridity in Korea: Conflicting interpretations of Korean culture by South Koreans and ethnic Korean Chinese marriage migrants. Asian Journal of Women's Studies, 21(3), 232-251. 
Seo Joong-Seok 2007: Korean Nationalism Betrayed. Global Oriental, Folkestone.

Seok, Hyun-Ho 2009: Globalization of labor and corporate enterprises in South Korea: labor relations and social adjustment ofmigrant workers. In Chang, Yun-Shik - HyunHo Seok - Donald L. Baker (eds.): Korea Confronts Globalization. Routledge, London, 118-139.

Seol, Dong-Hoon 2000: Past and Present of Foreign Workers in Korea 1987-2000. Asia Solidarity Quarterly, 2(1), 6-31.

Seol, Dong-Hoon - John D. Skrentny 2004: South Korea: importing undocumented workers. In Cornelius, Wayne A. - Philip L. Martin - James F. Hollifield (eds.): Controlling Immigration: A Global Perspective. Stanford University Press, Stanford, 418-513.

Seol, Dong-Hoon - John D. Skrentny 2009a: Ethnic Return of Migration and Hierarchical Nationhood: Korean Chinese Foreign Workers in South Korea. Ethnicities, 9(2), 147174.

Seol, Dong-Hoon - John D. Skrentny 2009b: Why is there so little migrant settlement in East Asia? International Migration Review, 43(3), 578-620.

Seth, Michael J. 2010: A Concise History of Modern Korea. From the Late Nineteenth Century to the Present. Rowman \& Littlefield Publishers, Lanham.

Seth, Michael J. 2011: A History of Korea. From Antiquity to the Present. Rowman, Lanham. Shen, Shawn 2016: The Bibimbap Migration Theory? Challenges of Korea's Multicultural Mix and Social Integration Development. International Migration \& Integration, online publikálva: 2016 június 1. 1-19. DOI: 10.1007/s12134-016-0489-6

Shin, Gi-Wook 2006: Ethnic Nationalism in Korea: Genealogy, Politics, and Legacy. Stanford University Press, Stanford.

Skrentny, John D. - Jack Jin Gary Lee 2014: Immigration, nationhood, and transnationlization in industrialized East Asia. In Soysal, Yasemin Nuhoğlu (ed.): Transnational Trajectories in East Asia: Nation, Citizenship, and Region. Routledge, New York, 130-155.

Son, Key-young 2006: South Korean Engagement Policies And North Korea: Identities, Norms And The Sunshine Policy. Routledge, London.

Song, Changzoo 2014: Engaging the diaspora in an era of transnationalism. South Korea's engagement with its diaspora can support the country's development. In Zimmermann, Klaus F. - Alexander S. Kritikos (eds.): Evidence-based Policy Making in Labor Economics: The IZA World of Labor Guide 2015. Bloomsbury, London, 74-76.

Special Act on Support For the Acquisition of Legitimate Residency Status And Settlement of Korean in the Old Soviet Union. Amended by Act No. 11690, Korea Legislation Research Institute. Ministry of Foreign Affairs. Mar. 23, 2013. http://elaw.klri.re.kr/eng_service/lawView.do?lang=ENG\&hseq=28442 Letöltve: 2016. augusztus 17.

Status of Marriage Migrant by Nationality. Ministry of Justice, Statistics of Registered Foreigners, Seoul. 2015.

Status of Registered Foreigners by Place of Residence and Sojourn Status. Ministry of Justice, Statistics of Registered Foreigners, Seoul. 2015.

The First Basic Plan for Immigration Policy (2008-2012). Seoul. Korea Immigration Service, Ministry of Justice, 2009. 
Tikhonov, Vladimir Mikhailovich 2010: Social Darwinism and nationalism in Korea: the beginnings (1880s-1910s): „,survival” as an ideology of Korean modernity. Brill, Leiden. United Nations, Department of Economic and Social Affairs 2013: Trends in International Migrant Stock: Migrants by Destination and Origin, (United Nations database, POP/ DB/MIG/Stock/Rev.2013).

Wang, Hong-Zen - Shu-Ming Chang 2002: The commodification of international marriages: cross-border marriage business in Taiwan and Vietnam. International Migration, 40(3), 93-116.

Watson, lan 2010: Multiculturalism in South Korea: A Critical Assessment. Journal of Contemporary Asia, 40(2), 337-346.

World-Okta to Hold Training Program for Young Overseas Koreans. KBS World Radio. May 17, 2014. http://world.kbs.co.kr/english/news/news_Ec_detail.htm?No=102630 (Letöltve: 2016. augusztus 13.)

Yoo, Kil-Sang 2003: Korea. In Trends in International Migration. Continuous Reporting System on Migration. Annual Report 2002 Edition. OECD, Paris, 210-214.

Yoo, Kil-Sang 2005: Foreign Workers in the Republic of Korea. Korea Labour Institute, Seoul.

Yoon, In-Jin 1997: On My Own: Korean Businesses and Race Relations in America. University of Chicago Press, Chicago.

Yoon, In-Jin 2012: Migration and the Korean Diaspora: A Comparative Description of Five Cases. Journal of Ethnic and Migration Studies, 38(3), 413-435.

Yu, Eui-Young 1983: Korean communities in America: Past, present, and future. Amerasia Journal, 10(2), 23-51.

Yu, Eui-Young - Peter Choe - Sang II Han 2002: Korean population in the United States, 2000: Demographic characteristics and socioeconomic status. International Journal of Korean Studies, 6(1), 71-107.

Yuh, Ji-Yeon 2002: Beyond the Shadow of Camptown: Korean Military Brides in America. New York University Press, New York.

김현미 2009: 방문취업 재중동포의 일경험과 생활세계. (A koreai kínaiak munkakörülményei és élettapasztalatai a H-2 vízummal.) 한국문화인류학. (Koreai társadalom a kulturális antropológiáért.), 42(2), 35-75.

서울경인지역평등노조 이주노동지부 2004: 미등록 이주 노동자 양산의 원인. (A tömeges illegális bevándorlás okai). 국민행동 소식지, 2004(28), Május 14, 2004. http:// antiwto.jinbo.net/faxpaper/view.php?table=faxpaper\&page=7\&lmode=normal\&field $=\&$ word=\&no=36 Letöltve: 2016. augusztus 15 .

오정미 2015: <단군신화>로 새롭게 보는 다문화사회 (A Tangun-mítosz egy multikulturális társadalomban). 다문화콘텐츠연구 (Multikulturális tartalom kutatás), 2015(19), 209-232. 
외교부 2015: 재외동포현황, (Külügymnisztérium, Határontúli koreaiak helyzete)

윤형숙 2005: 외국인 출신 농촌주부들의 갈등과 적응 - 필리핀 여성을 중심으로 (Koreai férfiak külföldi feleségeinek konfliktusai és alkalmazkodása: Filipina feleségek a falusi Koreában.) 지방사와 지방문화 (Helytörténeti és kulturális folyóirat), 8(2), 299-339.

정남옥 - 이명하 2010: 여성결혼이민자의 건강증진행위 예측모형. (A házasodni bevándorló nők egészség-magatartásának prediktív modellje.) 대한간호학회지, (A Koreai Gondozó Akadémia Folyóirata), 40(5), 695-704.

최홍엽 1996: 외국인 산업연수생제도와 고용허가제 (Az ipari gyakornoki program és az Alkalmazotti engedélyezési rendszer) 노동법연구 제 (Munkajogi tanulmányok), 5(6), 85-117.

출입국 · 외국인정책본부, 이민정보과: 2016 년도 6월호 통계월보 (Bevándorlási és idegenpolitikai szolgálat, Bevándorlási információs osztály: 2016 júniusi statisztika)

행정안전부 2011: 지방자치단체 외국인주민 현황 조사 (Közigazgatási és Biztonsági Minisztérium: Felmérés a külföldi lakosok helyzetéről).

허동현 2009: 한국 근대에서 단일민족 신화의 역사적 형성과정. (A homogén nemzet mítoszának történeti fejlődése). 동북아역사논총, (Északkelet-Ázsiai Történelmi Folyóirat), 2009 (23), 7-35. 


\title{
INTERNATIONAL MIGRATION AND MIGRATION POLICY IN SOUTH-KOREA
}

\begin{abstract}
The concept of South Korea as a homogenous nation determines its migration policy related to both the Korean diaspora, the labor force immigration and social integration. The Korean government openly deals with changing demographic environment in the last few decades, like decreasing fertility, aging society and shrinking population and all of its economic consequences. Recently it takes place in national economic planning and multicultural programs; albeit changes are directed by a centralized administration and happens to fast, such development still points in the direction of a more open society. Subordinating migration policy of economic interests remains decisive but human rights criteria are considered more and more in this regard too. The Korean Republic undergoes significant changes, immigration is increasing remarkably, and as a result Korea achieved an intermediate position in the larger East Asian region both geopolitically and in the context of migration flows.
\end{abstract}

